\title{
Massive synchronous B-cell necrosis causing Type 1 (insulin-dependent) diabetes - a unique histopathological case report
}

\author{
A. K. Foulis ${ }^{1}$, N.D. Francis ${ }^{2}$, M. A. Farquharson ${ }^{1}$ and A. Boylston ${ }^{2}$ \\ Departments of Pathology, ${ }^{1}$ Royal Infirmary, Glasgow and ${ }^{2}$ St. Mary's Hospital, London, UK
}

\begin{abstract}
Summary. A 22-year-old Chinese male died in hyperglycaemic coma following a $36-\mathrm{h}$ illness. The only significant pathological findings were in the pancreas where there was a heavy diffuse infiltrate of lymphocytes admixed with numerous eosinophils, macrophages and polymorphs. There appeared to have been massive, recent, synchronous necrosis of insulin-secreting B cells with no destruction of any other pancreatic parenchymal cells. The biochemical findings of
\end{abstract}

severe hyperglycaemia, insulinopoenia, but a normal glycosylated $\mathrm{HbA}_{1}$ were compatible with an acute onset to the patient's diabetes. These features contrast with the very much slower destruction of B cells associated with insulitis seen in "classical" Type 1 (insulin-dependent) diabetes.

Key words: Type 1 (insulin-dependent) diabetes, pancreas, histopathology.
It has long been held possible that viruses may be involved in the aetiology of some cases of Type 1 (insulin-dependent) diabetes. A Coxsackie B4 virus was isolated from the pancreas of a 10-year-old boy who presented in hyperglycaemic ketoacidosis and who died 8 days later [1]. The virus which was cultured was later shown to cause diabetes when injected into certain strains of mice. In a second case report a 5-yearold girl developed diabetes 19 days after heart surgery [2]. She died in coma and there was immunohistological evidence of Coxsackie B virus in the pancreatic islets. Serological studies have also been done on patients with newly diagnosed Type 1 diabetes and these have shown raised titres to Coxsackie $B$ viruses in a proportion of cases [3-5]. Initially it was thought that viral-induced diabetes would cause a massive simultaneous destruction of insulin-secreting $B$ cells and that the seasonality of presentation of Type 1 diabetes might be related to the seasonality of viral infections a situation akin to poliomyelitis. However, with the demonstration that islet cell antibodies may be present for years before presentation of the disease [6] and the finding of residual $\mathrm{C}$-peptide secretion in the majority of patients 2 years after presentation [7], it has become accepted that B-cell killing in the pancreas takes place over many years in the vast majority of patients with Type 1 diabetes. It has more recently been proposed that Coxsackie B viruses may not be involved in a direct cytopathic effect on $B$ cells but may stimulate an autoimmune reaction to $B$ cells [8].
We report the histological findings in the pancreas of a patient who died of insulin-dependent diabetes in whom there appeared to have been a total and almost simultaneous destruction of B cells. The histological features were suggestive of a viral aetiology.

\section{Case report}

The patient was a 22-year-old Chinese male who gave a $36-\mathrm{h}$ history of abdominal discomfort and vomiting. Prodromal diabetic symptoms such as polyuria, polydypsia and weight loss were lacking. There was no significant past medical history and no familiy history of diabetes. He had not knowingly taken any drugs or toxins. On admission to St. Mary's Hospital, London, he was hypotensive and dehydrated. His blood biochemical findings were as follows: $\mathrm{Na}, 111 \mathrm{mmol} / \mathrm{l}$; K,7.7 mmol/l; glucose, $92 \mathrm{mmol} / \mathrm{l}$; amylase, 148 Somogyi units $/ 100 \mathrm{ml}$ (Normal less than 180 ); arterial blood: $\mathrm{pH}, 7.1 ; \mathrm{pCO}_{2}, 16 \mathrm{~mm} \mathrm{Hg} ; \mathrm{pO}_{2}, 70 \mathrm{~mm} \mathrm{Hg}$; bicarbonate, $3.5 \mathrm{mmol} / \mathrm{l}$; Base excess - 22.9. He had a cardio-respiratory arrest $1 \mathrm{~h}$ after admission and resuscitation was unsuccessful. Other investigations which were done on blood taken prior to death included the following: plasma insulin, less than $2 \mathrm{mU} / 1$ (normal range 3-30) and a test for islet cell antibodies which proved negative. Unfortunately, no serum was sent for viral serological studies. A post mortem examination was performed $34 \mathrm{~h}$ after death. Blood taken at that time showed a glycosylated $\mathrm{HbA}_{1}$ of $7.1 \%$ (normal less than $8 \%$ ). Pathological findings at autopsy included pulmonary congestion, small erosions in the stomach associated with the presence of some altered blood, and approximately $200 \mathrm{ml}$ of slightly blood-stained fluid in the peritoneal cavity. All other organs, including the pancreas, were thought to be macrosopically normal. Liver, spleen, prostate, adrenal, aorta, thyroid, heart, lung, pancreas, kidney, testis, pituitary, stomach, brain and meninges were all sampled histologically. In the lung there was evidence of alveolar haemorrhage and there was a moder- 


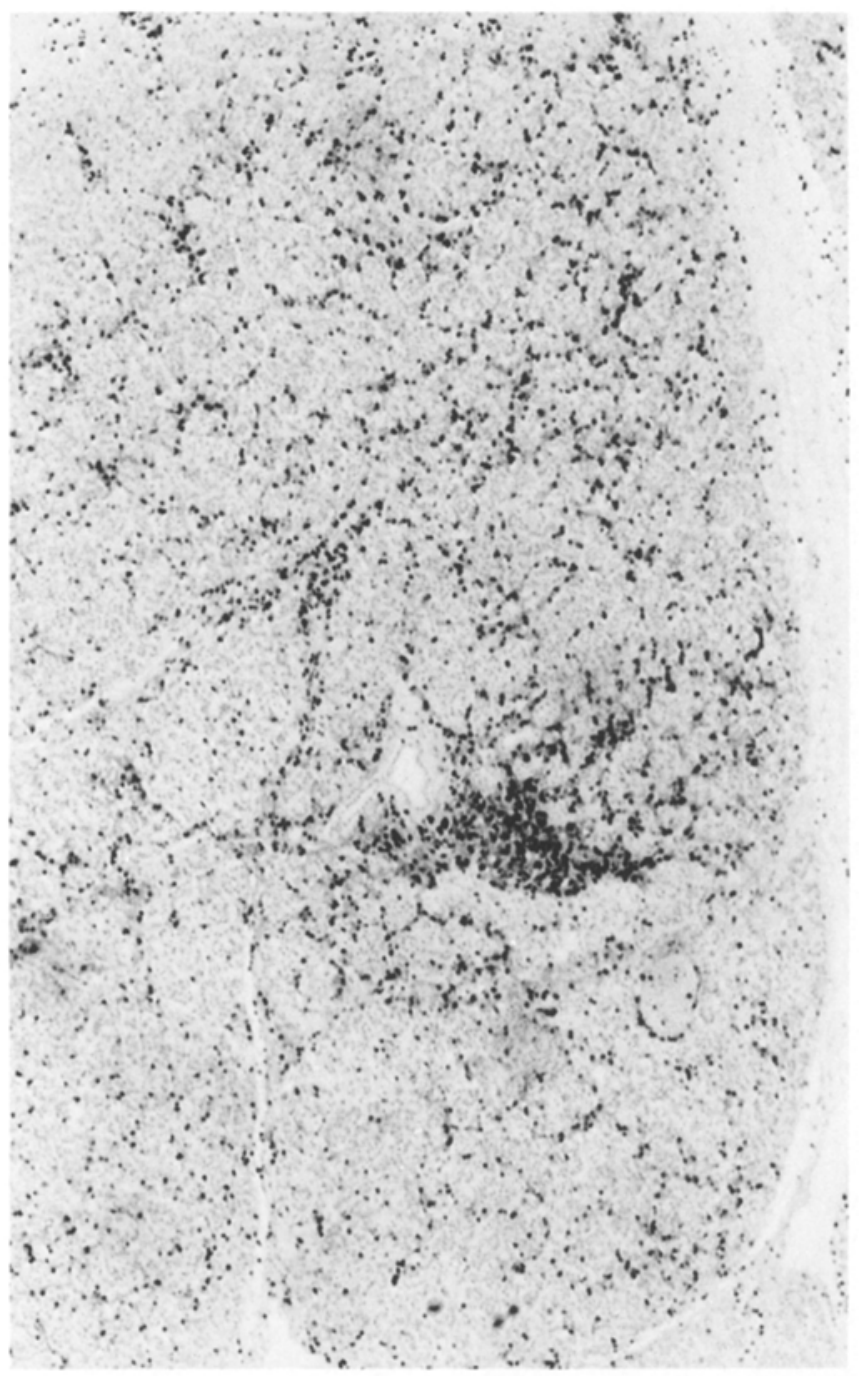

Fig. 1. Pancreatic lymphoid infiltrate. The section has been stained by indirect immunoperoxidase using PD7/26 as primary antibody. There is a diffuse infiltrate of lymphoid cells with little evidence of accentuation around islets $(\times 60)$

ate degree of fatty change in the liver. However, no evidence of hepatocellular necrosis was seen. The kidneys were normal apart from focal hyaline change affecting afferent arterioles in less than $1 \%$ of glomeruli. The remaining organs, with the exception of the pancreas, were unremarkable.

\section{Materials and methods}

Four micron serial sections were cut from the two blocks of formalin fixed paraffin embedded pancreas. Section one was stained by haematoxylin and eosin and section 7 by carbol chromotrope method (a specific stain for eosinophils). Sections two to six were stained by indirect immunoperoxidase techniques using the following primary antisera: guinea pig anti-insulin (Wellcome, Dartford, UK) rabbit anti-glucagon (Guildhay, Guildford, UK) rabbit anti-somatostatin (RIA UK Ltd., Tyne \& Wear, UK), rabbit anti-pancreatic polypeptide (Metachem Diagnostics Ltd., Northampton, UK), mouse monoclonal antibody PD7/26, which is directed against the T200 leucocyte common antigen, present on all lymphocytes [9] (gift from Dr. D. Y.Mason, Oxford, UK). The following bridges for the indirect techniques were used: peroxidase-conjugated rabbit anti-guinea pig, swine anti-rabbit and rabbit anti-mouse immunoglobulins (Dako, High Wycombe, England). The reactions were developed using diaminobenzidine as substrate.

Attempts were made to develop an immunohistochemical technique capable of demonstrating the presence of Coxsackie $B$ viral antigens on formalin fixed human autopsy tissues known to be infected with the virus. This proved unsuccessful.

\section{Statistical analysis}

Glycosylated $\mathrm{HbA}_{1}$ was measured using the Glytrac kit (Corning Medical). The method used was that advised by the manufacturers.

\section{Results}

\section{Pancreatic histology}

The most striking abnormality was a diffuse inflammatory cell infiltrate affecting both the exocrine and endocrine pancreas but with little evidence of accentuation around islets (Fig.1). The infiltrate consisted predominantly of small lymphocytes but with a moderate scattering of eosinophils, macrophages, and occasional mast cells (Fig.2). Polymorphonuclear leucocytes were present but were less frequent than eosinophils. Plasma cells were absent. There was no convincing evidence of acinar cell necrosis and in keeping with this there was no evidence of fat necrosis in the surrounding peripancreatic adipose tissue. Duct inflammation was absent. Significant abnormalities were present in the islets which were affected diffusely throughout the pancreas. Approximately one-third of the 330 islets available for study were indistinct on haematoxylin and eosin staining due to local oedema (Fig. 3a). Glucagon-secreting A cells and somatostatinsecreting $\mathrm{D}$ cells had not been destroyed in these islets and the cords of these cells were widely separated, as they would be in a normal islet (Fig. 3b). In between the cords of these cells there was some eosinophilic debris but endocrine cells showing obvious morphological signs of necrosis were not convincingly seen. There had been massive loss of B cells such that single B cells were present in only two islets (Fig. $3 \mathrm{c}$ ). The remaining islets were smaller, more compact and more readily discernable (Fig. 4a). They closely resembled the insulin deficient islets of classical Type 1 diabetes, in that $B$ cells were never demonstrable and the cords of A cells had become closely approximated (Fig. 4b). Pancreatic polypeptide-secreting PP cells were rare in both blocks of pancreas since the tissue had been taken from the PP-poor lobe.

\section{Discussion}

The pancreatic pathology in this case was different from that found in "classical" Type 1 diabetes in several respects. Firstly, the degree of exocrine inflamma- 

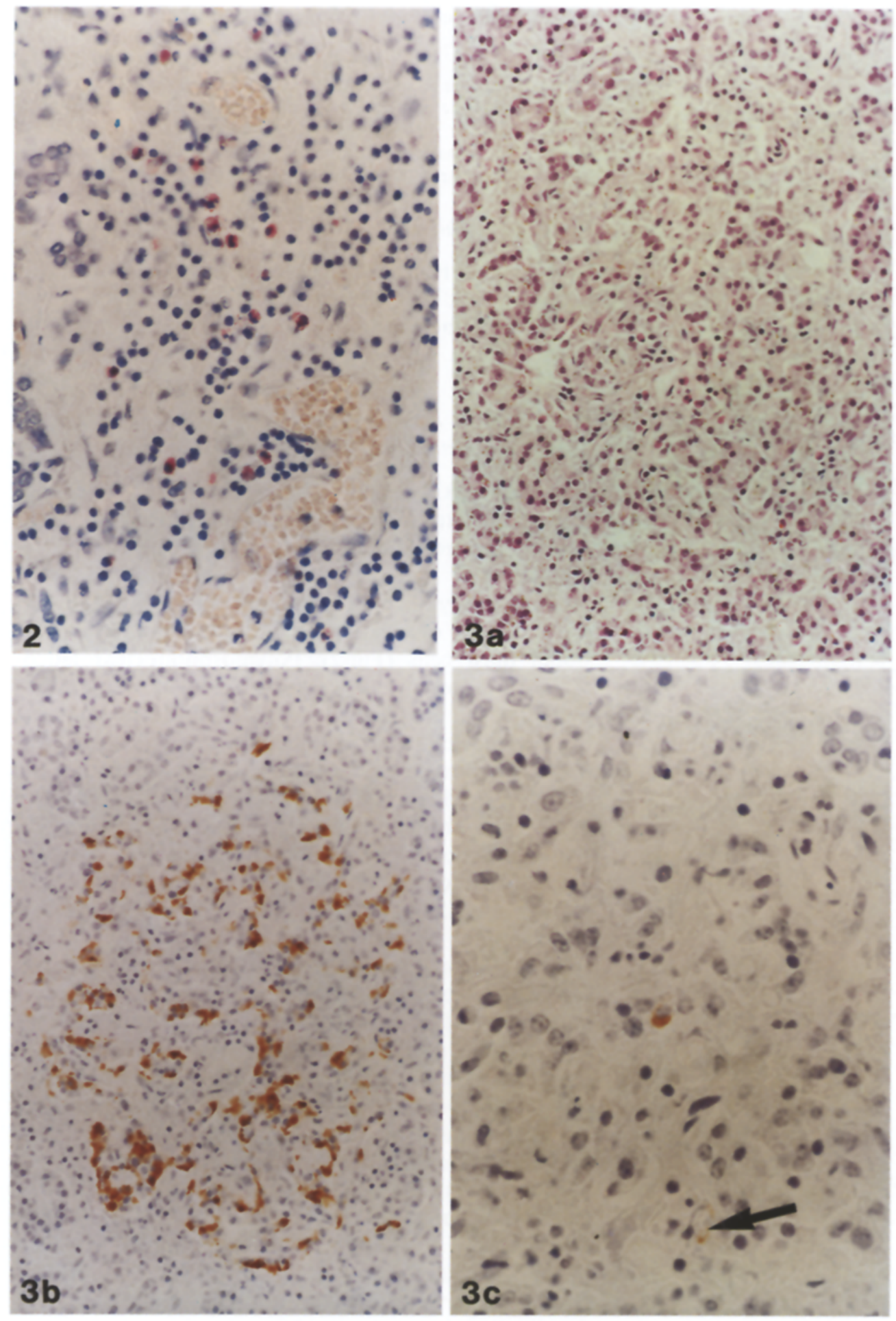

Fig. 2. Details of the pancreatic inflammatory infiltrate. In addition to small lymphocytes eosinophils are also present. (Carbol chromotrope $\times 310$ )

Fig.3a. An example of an oedematous swollen islet. The outline of the islet is indistinct and there is an inflammatory infiltrate which includes eosinophils. Acinar cell necrosis is absent. (Haematoxylin and eosin $\times 150)$

Fig.3b. This adjacent section to that shown in Figure 3 a has been immunostained for glucagon. A cells are preserved and the cords of these cells are separated, as they would be in a normal islet $(\times 150)$

Fig.3c. This adjacent section to that shown in Figure $3 \mathrm{~b}$ has been immunostained for insulin. One residual insulin containing cell is present in the middle of the picture. Some immunoreactive insulin, apparently not in a cell, is present below this (arrow) $(\times 380)$

tion was striking, with little evidence of accentuation of inflammatory cells around islets. While chronic inflammatory cells have been noted in the exocrine pancreas before in patients with recent-onset Type 1 diabetes the degree of inflammation has always been distinctly less [10]. Secondly, the presence of large numbers of eosinophils in the inflammatory infiltrate in Type 1 diabetes has never previously been recorded. Thirdly, although cases of recent onset Type 1 diabetes have been seen in which no B cells were present $[10,11]$ the swollen insulin deficient islets in the present case were quite atypical.

It has been noted that in alloxan induced B-cell necrosis in rabbits there was total B-cell necrosis within hours of administration of the drug. Five days later all trace of B cells had gone and the remaining $A$ and $D$ cells had approximated to each other to form compact insulin deficient islets [12]. Thus the compact insu- 


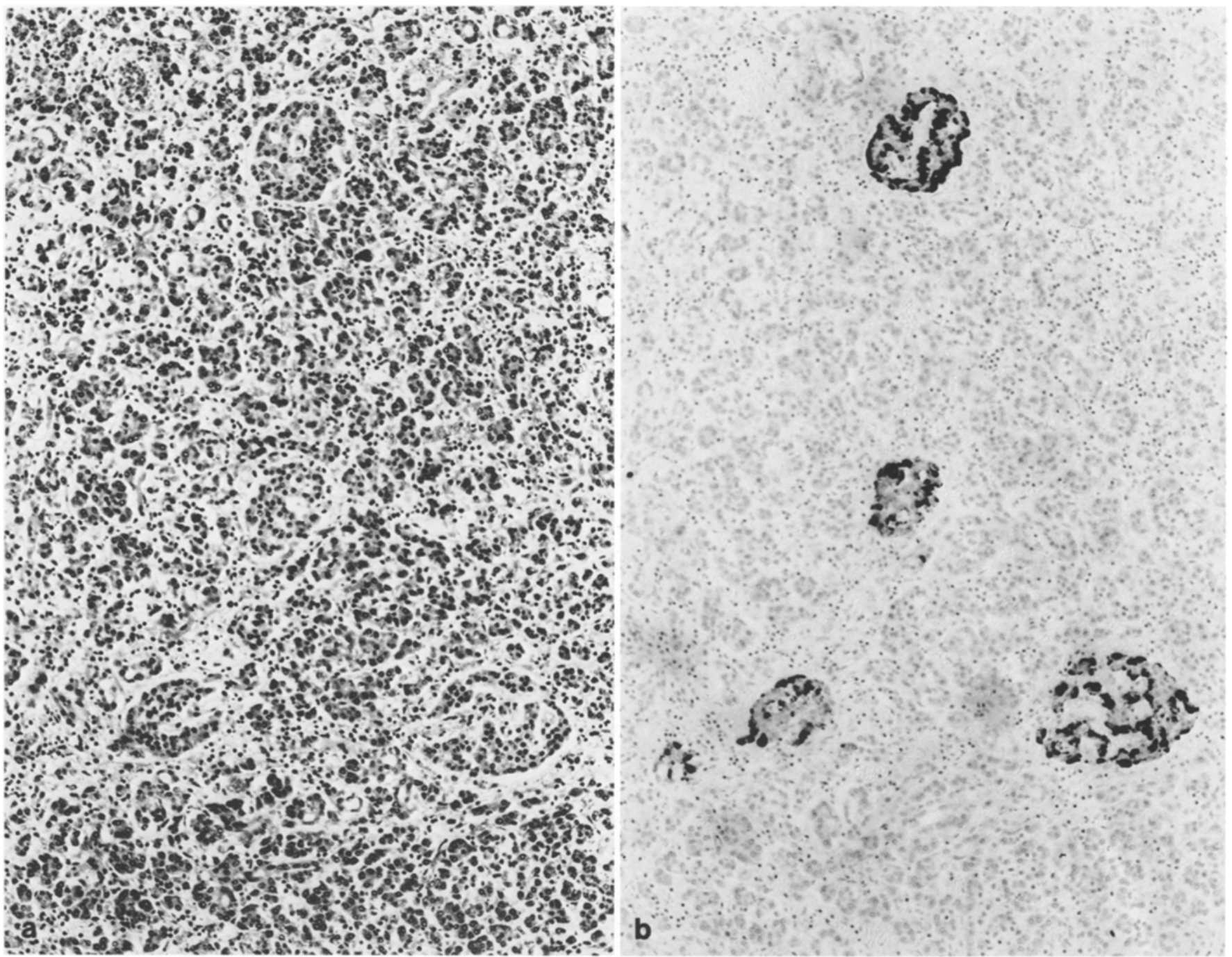

Fig.4a. Compact insulin deficient islets. Four readily discernible islets are present (Haematoxylin and eosin $\times 130$ )

Fig. 4 b. This adjacent section to that shown in Figure $4 \mathrm{a}$ has been immunostained for glucagon. A cells are preserved and the islets are more collapsed than that shown in Figure $3 \mathrm{~b}$. Insulin secreting B cells were not found in these islets $(x 130)$

lin deficient islets seen in the present case could probably have formed following massive B-cell necrosis within the week prior to the patient's death. The appearance of the swollen oedematous insulin-deficient islets would be compatible with islets in which there had been slightly more recent B-cell necrosis but in which the residual non-B cells had not yet come together to form collapsed insulin deficient islets. The finding of striking hyperglycaemia, hypoinsulinaemia and a normal glycosylated $\mathrm{HbA}_{1}$ would all be compatible with such a scenario.

It is fully recognised that there is no proof in this case that the B-cell death was due to a cytopathic viral infection. The absence of any history of drug ingestion and the lack of any necrosis in liver or kidney help to make toxic damage to the $B$ cells, as a result of a chemical poison, less likely.

There is little information in the literature on the histopathological features of mumps infection of the pancreas but, at least in the neonatal period, it has been shown that Coxsackie $B$ viral infection can cause lytic damage to pancreatic B cells as well as other islet endocrine cells $[13,14]$. Eosinophils have not previously been associated with inflammation due to Coxsackie infection. However, one of us has had the opportunity to examine 12 pancreata from children under 1 year of age who died of culture proven Coxsackie B viral myocarditis. Pancreatic endocrine cell necrosis was present in four patients; and in two the inflammatory cell infiltration in both pancreas and heart showed a striking number of eosinophils [15]. Thus, the presence of eosinophils in the pancreas in the present case would at least be compatible with an aetiology such as Coxsackie B viral infection.

The two fatal cases of Type 1 diabetes in whom Coxsackie B virus was demonstrated in the pancreas were both atypical of Type 1 diabetes clinically and had a different histological appearance from this pre- 
sent case. The child reported by Yoon et al. [1] had clinical evidence of aseptic meningitis and Coxsackie B viral protein was demonstrated in CNS cells in the brain stem. The child reported by Gladisch et al. [2] had severe viral myocarditis in addition to diabetes. Both encephalitis and myocarditis are distincly unusual accompaniments to the presentation of Type 1 diabetes. The pancreatic pathology of these two cases has been reviewed by Gepts [16]. He found much less severe exocrine inflammation than that seen in the present case. Also insulin containing islets were plentiful and insulitis was present. Thus there are several points of difference between the findings in these previously reported cases and the one recorded here.

It is now recognised that in typical cases of Type 1 diabetes killing of $\mathrm{B}$ cells takes place over a long period of time $[6,7,10,17,18]$. It has been argued that in the present patient the B cells may have been killed over as short a time period as 1 week. This case came to light during a survey of all deaths in young diabetic patients in the United Kingdom over a 25-year period [10]. It is unique in this collection and yet, because of the severity and speed of the B-cell destruction, cases such as this would be expected to be over-represented in any autopsy series. This serves to emphasise that if a virus can cause a massive cytopathic effect of pancreatic $B$ cells, as has been suggested in this case, it must be a very rare event indeed.

Acknowledgements. We are grateful to Dr. D. Y. Mason (Oxford) for the gift of the antibody PD7/26. Ms. M. Habbick and Ms. I. Main kindly prepared the manuscript. M.A.F. is supported by Tenovus, Scotland.

\section{References}

1. Yoon JW, Austin M, Onodera T, Notkins AL (1979) Virus induced diabetes mellitus. N Engl J Med 300: 1173-1179

2. Gladisch R, Hofmann W, Waldherr R (1976) Myokarditis und Insulitis nach Coxsackie-Virus-Infekt. Kardiol 65: 837-849

3. Gamble DR, Taylor KW, Cumming H (1973) Coxsackie viruses and diabetes mellitus. Br Med J 4: 260-262

4. Banatvala JE, Bryant $\mathbf{J}$, Schernthaner $G$, Borkenstein $M$, Schober E, Brown D, DeSilva LM, Menser MA, Silink M (1985) Coxsackie B, Mumps, Rubella and cytomegalovirus specific IgM responses in patients with juvenile - onset insulin - dependent diabetes mellitus in Britain, Austria and Australia. Lancet I: 1409-1412

5. Eberhardt MS, Wagener DK, Orchard TV, LaPorte RE, Cavender DE, Rabin BS, Atchison RW, Kuller LH, Drash AL, Becker DJ (1985) HLA heterogeneity of insulin-dependent diabetes mel- litus at diagnosis. The Pittsburgh IDDM study. Diabetes 34: 1247-1252

6. Gorsuch AN, Spencer KM, Lister J, McNally JM, Dean BM, Bottazzo GF, Cudworth AG (1981) Evidence for a long prediabetic period in Type I (insulin-dependent) diabetes mellitus. Lancet II: $1363-1365$

7. Mustonen A, Knip M, Huttunen NP, Puukka R, Kaar ML, Akerblom HK (1984) Evidence of delayed Beta cell destruction in Type 1 (insulin-dependent) diabetic patients with persisting complement - fixing cytoplasmic islet cell antibodies. Diabetologia 27: 421-426

8. Schernthaner G, Banatvala JE, Scherbaum W, Bryant J, Borkenstein M, Schober E, Mayr WR (1985) Coxsackie-B-Virus-specific IgM responses, complement-fixing islet-cell antibodies, HLADR antigens and C-peptide secretion in insulin-dependent diabetes mellitus. Lancet II: 630-632

9. Warnke RA, Gatter KC, Falini B, Hildreth P, Woolston RE, Pulford $\mathrm{K}$, Cordell JL, Cohen B, DeWolf-Peters C, Mason DY (1983) Diagnosis of Human Lymphoma with monoclonal antileukocyte antibodies. N Engl J Med 309: 1275-1281

10. Foulis AK, Liddle CN, Farquharson MA, Richmond JA, Weir RS (1986) The histopathology of the pancreas in Type 1 (insulindependent) diabetes mellitus: a 25 year review of deaths in patients under 20 years of age in the United Kingdom. Diabetologia 29: $267-274$

11. Gepts W, De Mey J (1978) Islet cell survival determined by morphology. An immunocytochemical study of the islets of Langerhans in juvenile diabetes mellitus. Diabetes 27 [Suppl 1]: 251-261

12. Meehan CJ, Davidson PM, Young DG, Foulis AK (1987) The partially diabetic pancreas: A histological study of a new animal model. Pancreas 2: 91-98

13. Jenson AB, Rosenberg HS, Notkins AL (1980) Pancreatic isletcell damage in children with fatal viral infections. Lancet II: 354-358

14. Ujevich MM, Jaffe R (1980) Pancreatic islet cell damage. Its occurrence in neonatal Coxsackie virus encephalomyocarditis. Arch Pathol Lab Med 104: 438-441

15. Foulis AK, Farquharson MA, Hardman R (1987) Aberrant expression of Class II major histocompatilibity complex molecules by $B$ cells and hyprexpression of Class I major histocompatibility complex molelcules by insulin containing islets in Type 1 (insulin-dependent) diabetes mellitus. Diabetologia 30:333-343

16. Gepts W, LeCompte PM (1985) The pathology of Type 1 diabetes. In: Volk BW, Arquilla ER (eds) The diabetic pancreas, 2nd edn. Plenum, New York, pp 337-365

17. Gepts W (1965) Pathologic anatomy of the pancreas in juvenile diabetes mellitus. Diabetes 14: 619-633

18. Tarn AC, Smith CP, Spencer KM, Bottazzo GF, Gale EAM (1987) Type 1 (insulin dependent) diabetes: a disease of slow clinical onset? Br Med J 294: 342-345

Received: 17 July 1987

and in revised form: 3 November 1987

Dr. A. K. Foulis

Department of Pathology

Royal Infirmary

Glasgow G4 OSF

UK 